\title{
Article
}

\section{Relationship between building intelligence and sustainability}

Gadakari, Tulika, Hadjri, Karim and Mushatat, Sabah

Available at http://clok.uclan.ac.uk/20803/

Gadakari, Tulika, Hadjri, Karim ORCID: 0000-0001-8243-8396 and Mushatat, Sabah (2017) Relationship between building intelligence and sustainability. Proceedings of the Institution of Civil Engineers - Engineering Sustainability, 170 (6). pp. 294-307. ISSN 1478-4629

It is advisable to refer to the publisher's version if you intend to cite from the work. http://dx.doi.org/10.1680/jensu.16.00028

For more information about UCLan's research in this area go to

http://www.uclan.ac.uk/researchgroups/ and search for <name of research Group>.

For information about Research generally at UCLan please go to http://www.uclan.ac.uk/research/

All outputs in CLoK are protected by Intellectual Property Rights law, including Copyright law. Copyright, IPR and Moral Rights for the works on this site are retained by the individual authors and/or other copyright owners. Terms and conditions for use of this material are defined in the policies page.

\section{CLoK}

Central Lancashire online Knowledge www.clok.uclan.ac.uk

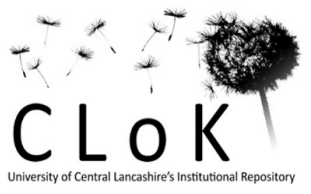


Relationship between Building Intelligence and Sustainability

\section{Tulika Gadakari, PhD}

Grenfell-Baines Institute of Architecture, School of Art, Design and Fashion, University of Central Lancashire, Preston, UK

\section{Karim Hadjri, PhD}

Grenfell-Baines Institute of Architecture, School of Art, Design and Fashion, University of Central Lancashire, Preston, UK

\section{Sabah Mushatat, PhD}

School of Energy, Geoscience, Infrastructure and Society, Heriot-Watt University, Dubai, UAE

\section{Full contact details of corresponding author.}

Tulika Gadakari, PhD

Grenfell-Baines Institute of Architecture, School of Art, Design and Fashion, University of Central Lancashire, Preston, UK tgadakari@uclan.ac.uk 


\section{Abstract}

A number of buildings worldwide are achieving 'Sustainability Scores' on being assessed by Green Building Rating Systems. These buildings employ a wide range of intelligent building technologies (IBTs) to varying degrees. In order to determine a relationship between building intelligence and sustainability it was strategized that the IBTs used in these buildings need to be analysed to assess their impact on the Sustainability Scores. Forty BREEAM and LEED certified buildings were chosen from UK and Europe. The data collected from these buildings was subjected to qualitative and quantitative analysis methods. Bi-variate correlation, regression analysis and 5-fold cross validation provided a best-fit logarithmic model that predicts the sustainability score of a building as an estimate value, based on the number of IBTs. Two overarching themes emerged: how the number and type of IBTs affect the sustainability score and how there needs to be an optimisation between the user's needs, building's functionality, and core intelligence function of the technology versus the prescriptive parameters imposed by rating systems. A positive correlation was observed between the two variables. The buildings reported reduction in: $41 \%$ energy consumption, $39 \%$ water consumption and $36 \% \mathrm{CO}_{2}$ emissions. Additionally significant benefits were noted on the economic and social front.

\section{Keywords chosen from ICE Publishing list}

Buildings; Codes of practice and standards; Control systems; Environment; Research and development; International development; Energy; Assessment; Systems

\section{List of notation}

$\begin{array}{ll}\text { BREEAM } \quad \text { Building Research Establishment Environmental Assessment Methodology } \\ \text { LEED } & \text { Leadership in Energy and Environmental Design } \\ \text { BMS } & \text { Building Management System } \\ \text { EMS } & \text { Energy Management System } \\ \text { FMS } & \text { Facilities Management System } \\ \text { ICS } & \text { Integrated Communications System } \\ R & \text { Pearson Correlation or R value } \\ x & \text { number of intelligent building technologies }\end{array}$




\section{Introduction}

An intelligent building is defined as a dynamic and responsive infrastructure that integrates disparate building systems such as lighting, HVAC, security, facilities management, etc. to effectively manage resources, provide high performance benefits and optimise processes, comfort, energy costs and environmental benefits. (Clements-Croome, 1997; Harrison et al., 1998; Sharples et al., 1999; Wacks, 2002; Clarke, 2008) Over the past 35 years, intelligent buildings have evolved, owing to technological maturity, web-enabled integration platforms, solid industry standards and increased market demand to become mainstream, practical and economical. (Ehrlich, 2007) The current scenario and speculation of advances in the fields of Al, robotics and architecture, confirm that intelligence in buildings is a sign of technological progress and it has been foreseen that by 2020 , most of the buildings around the world will be increasingly intelligent. (Nikolaou et al., 2004; Kurzweil, 2005)

Buildings are responsible for at least $40 \%$ of energy consumption in most countries. All buildings in the UK account for $45 \%$ of all energy use and $43 \%$ of all carbon emissions. (Garner, 1996; Harris, 2004; Pitts, 2004; Kinver, 2011; Robinson et al., 2016) As energy prices climb and the focus on environmental performance intensifies, buildings will have to make extra efforts to steer towards the sustainable way. With the advent of building intelligence, in the times when sustainable development is a rising concern, it is quite necessary to determine the relationship that exists between these two multi-dimensional entities so as to help the agenda of comfort, safety, energy efficiency, and monetary savings. (Gadakari et al., 2014)

This paper proposes that both sustainability and intelligence are multi-dimensional entities that are defined by and measure different things. It aims to find the true relationship between them and the nature of correlation i.e. if building intelligence would aid sustainability or not. Currently there are a number of Green Building Rating Systems that are helping in designing and assessing an ever-increasing number of buildings worldwide. The sustainability value of these buildings is judged based on various parameters such as energy performance, water efficiency, materials, air quality, etc. to achieve a Sustainability Score. It is evident that most of the current stock of buildings employed intelligent building technologies (IBTs) to varying degrees. In order to find a relationship between intelligence and sustainability in buildings it was strategized that the IBTs used in these 'certified Green' buildings need to be analysed so as to assess their impact on the Sustainability Scores achieved. It was hypothesized that if IBTs enhanced the sustainability of a building then as the number of IBTs used in a building increased, their Sustainability score would also increase. 40 BREEAM (Building Research Establishment Environmental Assessment Methodology) and LEED (Leadership in Energy and Environmental Design) certified commercial buildings were chosen from all over the UK and Europe as case studies. 
BREEAM and LEED were chosen for this research as they are the two most widely used thirdparty verification for green buildings around the world. Across 77 countries there are nearly 545,291 BREEAM issued certificates, and almost 2,244,962 buildings registered for assessment since it was first launched in 1990. LEED was first launched in 1994 and currently nearly 75,000 projects are registered and certified by LEED. (Roderick et al., 2012; Haroglu, 2013; BRE, 2016; USGBC, 2016) Both of the systems have a comprehensive and updated database of certified buildings.

\section{Data Collection and Analysis Strategy}

\subsection{Data Collected}

Of the 40 buildings selected, 31 were certified by BREEAM and 9 by LEED. BREEAM was launched in the UK and takes its cue from European and UK legislation while LEED launched in the US is dominated by the American ASHRAE standards. Furthermore most of the certified BREEAM buildings are in the UK while LEED has only 100 registered in the UK. BREEAM is thoroughly embedded in the system, appearing in planning policies across the UK and Europe. Certain European countries such as the Dutch Green Building Council have also adopted BREEAM as their favoured method. (BSRIA, 2009; Starrs, 2010; Cheshire, 2012) This has given rise to the unbalanced distribution of BREEAM and LEED case studies in spite of which common overall trends were observed in both the sets that explain the relationship. Further study could be undertaken with a larger LEED set in a different global region before generalising to a larger population.

A variety of case study buildings were chosen such that the final data set contains a mix of all the possible ratings that are achievable on the BREEAM and LEED rating systems. All of the chosen buildings were commercial (office, retail, mixed use) in nature to maintain uniformity in the typology. The buildings were distributed in different countries in the following way: UK (22), France (6), Belgium (2), Poland (2), Sweden (2), Germany (1), Spain (1), Luxembourg (1), Greece (1), Bulgaria (1) and Romania (1). Mainly three kinds of data was collected:

- Type of intelligent building technologies used

- Sustainability score achieved

- Other environmental features used in the buildings that do not fit the definition of IBTs data about each case study building's characteristics such as passive design strategies, site, materials, etc.

\subsection{Analysis Strategy}

The type of IBTs used in the individual case studies was the most emphasized data collected. Additionally data that reported the various benefits achieved by using these IBTs (such as energy and water savings, reduced $\mathrm{CO}_{2}$ emissions, economic benefits, health and well-being of occupants, etc.) was also collected. All of the case studies were split in groups based on the 
sustainability score/rating achieved and analysed within these groups as well as inter group so as to observe patterns, make relevant observations and detect any anomalies. The findings were then aggregated across a series of individual case studies so as to strengthen the quality of the research. (Creswell, 2009; Yin, 2009)

The data collected from the case studies was mainly qualitative, which was then inspected so as to identify the IBTs used and segregate them in the respective sub-categories of intelligent building systems. The Hollywood House in Woking, UK has been awarded the highest ever LEED PLATINUM score in the UK and also has the highest number of IBTs recorded among all the case studies in this research. (Skanska, 2012; Hollywood House, 2013) This particular case study has been chosen as an example to demonstrate the procedure used (Table 1).

It can be noted from Table 1 that the Hollywood House employed the use of 21 IBTs in total. The same procedure was followed with the rest of the case studies and each of their IBTs were identified, compartmentalised in the respective sub-categories of intelligent building systems and enumerated. All the individual buildings with their enumerated IBTs were then subjected to quantitative analysis. Bivariate Correlation Analysis was carried out first to help determine if the two variables i.e. building intelligence (number of IBTs) and sustainability (sustainability score) are correlated and to ascertain a trend. After considering the results from the correlation analysis, as a means of further exploring the complex relationship of the two variables, Regression Analysis and 5-Fold Cross Validation was conducted.

Table 1. Intelligent Building Technologies found in the Case Study of Rashleigh Weatherfoil divisional head office at Hollywood House, Woking, UK

\begin{tabular}{|c|c|c|}
\hline $\begin{array}{l}\text { Intelligent Building System } \\
\text { Categories }\end{array}$ & $\begin{array}{l}\text { Intelligent Building Systems Present in the } \\
\text { Analysed Building }\end{array}$ & $\begin{array}{l}\text { Number of } \\
\text { IBTs Used }\end{array}$ \\
\hline $\begin{array}{l}\text { Building Management Systems } \\
\text { (BMS) }\end{array}$ & Building Management System & 1 \\
\hline $\begin{array}{l}\text { Energy Management System } \\
\text { (EMS) }\end{array}$ & $\begin{array}{l}\text { - Energy management system } \\
\text { - Centralised automatic 'Power Off ' function }\end{array}$ & 2 \\
\hline $\begin{array}{l}\text { Facilities Management System } \\
\text { (FMS) }\end{array}$ & $\begin{array}{l}\text { - Green Building Management System } \\
\text { - Thermal monitoring system } \\
\text { - Water monitoring system } \\
\text { - } \mathrm{CO}_{2} \text { emissions monitoring system }\end{array}$ & 4 \\
\hline $\begin{array}{l}\text { Integrated Communications } \\
\text { System (ICS) }\end{array}$ & Complete integration of all systems & 1 \\
\hline Lighting System & $\begin{array}{l}\text { - Intelligent Lighting System } \\
\text { - Digital Addressable Lighting Interface (DALI) }\end{array}$ & 2 \\
\hline HVAC Control System & $\begin{array}{l}\text { - Zoned HVAC System } \\
\text { - Ventilation on demand } \\
\text { - Ventilation system with night time purging } \\
\text { - HVAC with Heat recovery system }\end{array}$ & 4 \\
\hline $\begin{array}{l}\text { Water Management System } \\
\text { Security System } \\
\text { Fire and Life Safety System } \\
\text { Monitoring System }\end{array}$ & Taps and toilets with occupant sensors & 1 \\
\hline
\end{tabular}


AV Control System

Feedback and Display System

- Traffic Light System

2

- Warning Display if any system exceeded set

Building/Tenant Scheduling benchmarks

System

Elevator \& Escalator System

Sensors and Sensor Networks

- Daylight Sensors

4

- Occupancy Sensors

- Temperature Sensors

- Carbon dioxide Sensors

\section{Correlation Analysis}

\subsection{Cross Case Analysis}

Standards for BREEAM awards are set at: GOOD, VERY GOOD, EXCELLENT and

OUTSTANDING whereas standards for LEED awards are set at: CERTIFIED, SILVER, GOLD and PLATINUM. All the case studies were split in groups based on the BREEAM/LEED award they achieved and analysed within these groups as well as intergroup, such as GOOD and CERTIFIED rating groups (3.1.1 to 3.1.4). Cross case analysis is a qualitative analysis rather than a quantitative one. The case studies were given ID's such as $\mathrm{G} 1$-[number] for the purpose of shorthand, easy identification and depiction on graphs (Refer to the Appendix). Following the procedure described for the example case study of Hollywood House in section 2.2 the number of IBTs present in every case study are statistically depicted in Figures 1 and 2.

It was observed (Figure 1) that the number of IBTs in the GOOD rated buildings ranged from 0 to 2; VERY GOOD rated buildings ranged from 3 to 6 ; EXCELLENT rated buildings ranged from 4 to 16; and OUTSTANDING rated buildings ranged from 9 to 10. It was also observed (Figure 2) that the number of IBTs in the CERTIFIED rated buildings ranged from 0 to 2; SILVER rated buildings ranged from 2 to 3 ; GOLD rated buildings ranged from 6 to 16 ; and PLATINUM rated buildings ranged from 8 to 21 . Figure 3 is showing the average values of the number of IBTs in each certification type and highlights a definitive trend that the buildings that have achieved a better Sustainability Rating, have a higher number of IBTs used in them.

It should be noted that all of the case study buildings had certain other environmental features present that though did not fit the definition of IBTs would affect the achieved sustainability score significantly. These were considered during analysis as rival explanations that could affect the causal relation between the variables and provided explanations for the outliers that were observed. While comparing case studies within a group, their 'other environmental features' were also compared. 


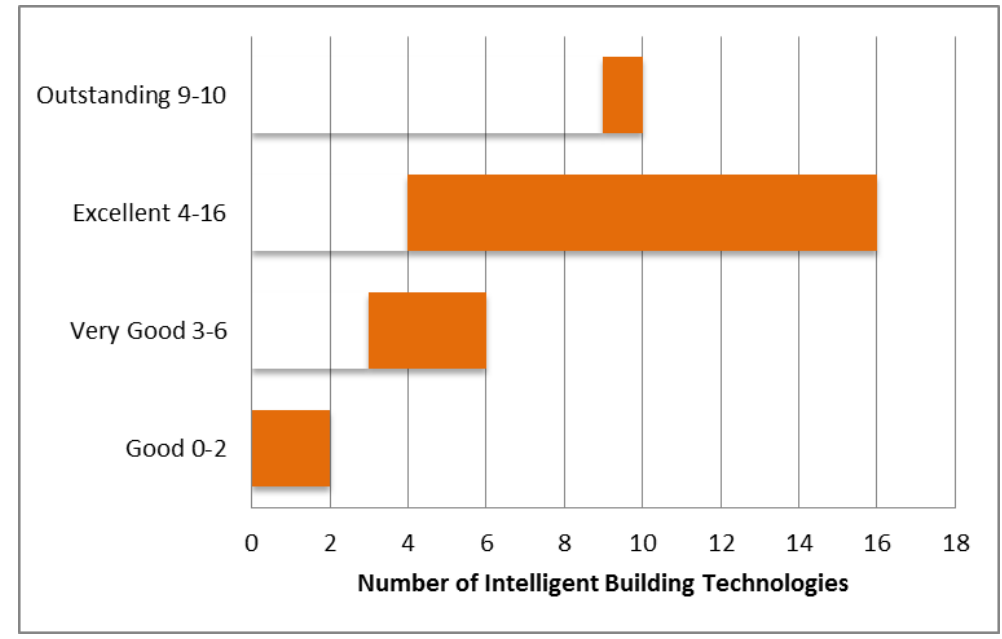

Figure 1: Range of the number of IBTs found in the analysed case studies certified by Breeam

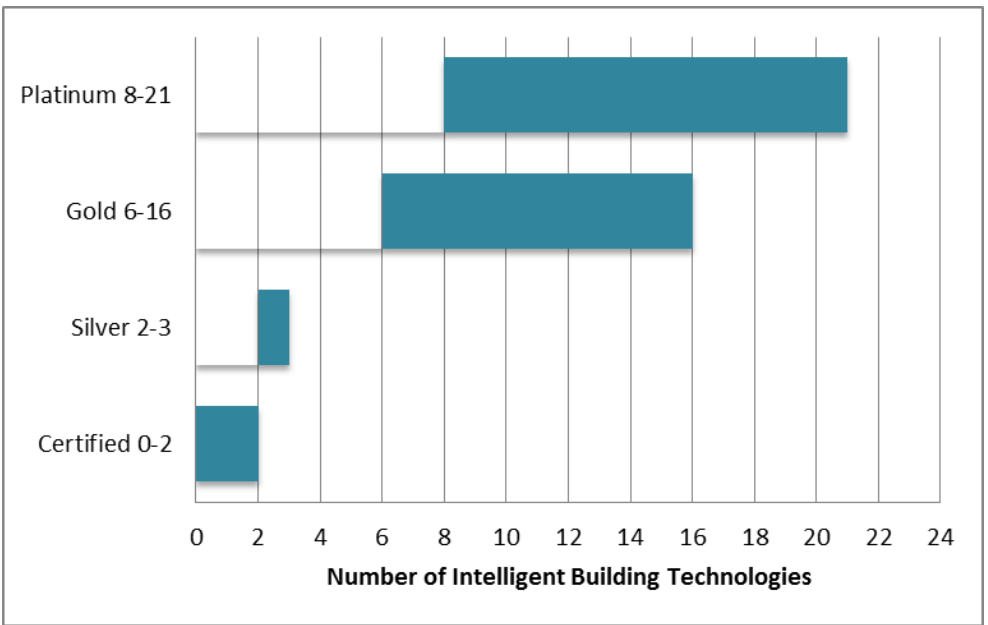

Figure 2: Range of the number of IBTs found in the analysed case studies certified by Leed

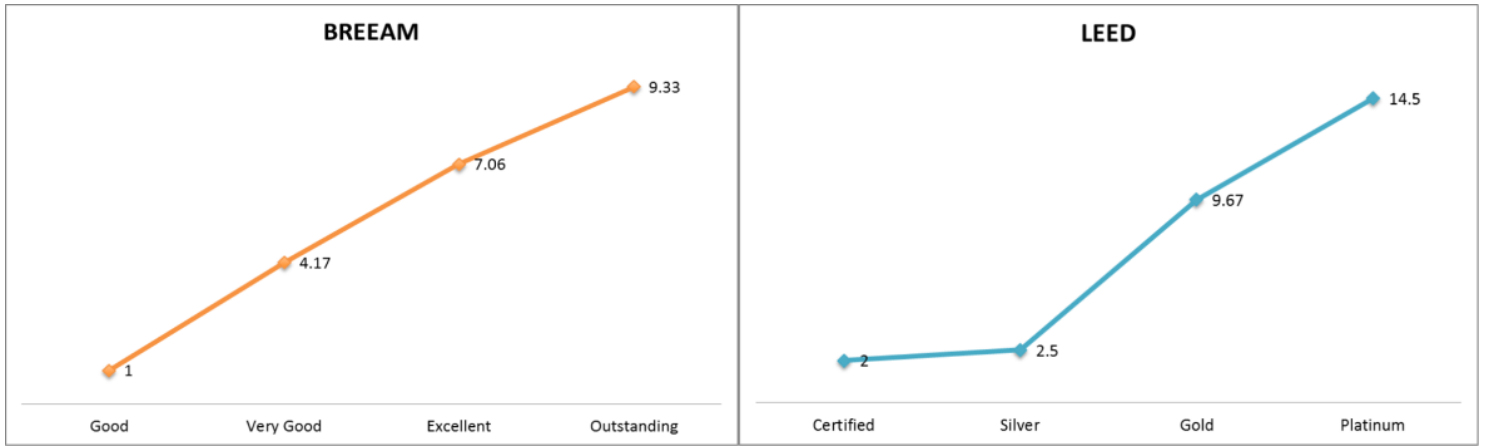

Figure 3: Average number of IBTs present in each rating category of Breeam and Leed

\subsubsection{GOOD and CERTIFIED Buildings}

Buildings G1-19 and G1-18, had a total of 2 IBTs used and it should be noted that the higher scoring building (G1-18) employed the use of a full-fledged BMS while the lower scoring building (G1-19) only used stand-alone monitoring and detection systems. 
Of the two buildings G1-37 and G1-38 that were rated as CERTIFIED by LEED, both made use of intelligent lighting management systems with daylight and occupancy sensors but the slightly higher scoring building (G1-38) among the two, additionally utilised a carbon dioxide monitoring system that improved the ventilation and air quality.

\subsubsection{VERY GOOD and SILVER Buildings}

It was observed that G1-36 scores better on the LEED scale than G1-33, thus revealing how IBTs, which promote resource efficiency help a building score more points. Both these buildings have used the same number of IBTs but the systems used in G1-33 promote building intelligence in the network, connectivity and AV control arena while G1-36 uses IBTs that promote resource efficiency in terms of intelligent lighting and self-controlling eco-power units that power down plug loads when not in use.

\subsubsection{EXCELLENT and GOLD Buildings}

Buildings G1-4 and G1-6 have used a total number of 4 IBTs and similar non-intelligent environmental features in them. In spite of which it was observed that G1-4 surpasses building G1-6's BREEAM score by a high margin. On closer scrutiny of the type of IBTs used, it was noted that G1-4 made use of an intelligent zoned HVAC system with heat recovery features and monitoring systems for water and $\mathrm{CO}_{2}$ emissions while $\mathrm{G} 1-6$ utilised an intelligent lighting system with occupancy and daylight sensors and a monitoring system for energy and water. It can be inferred that an intelligent HVAC system has a larger impact on the sustainability score than an intelligent lighting system.

Buildings G1-28 and G1-30 have used a total number of 5 IBTs in them, though G1-28 scores considerably more BREEAM points than G1-30. Both the buildings have used systems that help with energy efficiency, though the systems used in G1-30 predominantly lean towards providing occupant comfort such as centrally monitored climate control zones with an automatically resetting HVAC system along with automatically operable windows, facades and sun shading devices. In contrast, building G1-28 uses a BMS for complete control of the building, individually sub-metered energy zones, a lighting management system and intelligent escalators \& elevators with energy saving controls. Another example of a lack of BMS affecting scores drastically is noticed in buildings G1-3 and G1-5 which have used equal number of IBTs in them.

The Herman Miller International Headquarters, UK (G1-34) is one of a kind as it has been rated by both BREEAM and LEED rating systems to obtain EXCELLENT and GOLD ratings respectively. This building employs a large number of IBTs but scores relatively low on both the systems. This building has made use of a lighting management system, a demand controlled ventilation system, operable windows with fanlight openings that are automated using 
temperature and $\mathrm{CO}_{2}$ sensors, sensors for water leak detection and water monitoring. All of these automations are stand alone and not integrated via a BMS. It should be noted that case studies G1-35 and G1-40, belonging to this group, have scored the same points as G1-34 using a considerably lesser number of IBTs. Closer scrutiny of both these cases reveals that there is more emphasis on energy monitoring and facilities management systems while G1-34 lays more emphasis on comfort and convenience.

\subsubsection{OUTSTANDING and PLATINUM Buildings}

All the buildings in this group utilise the largest number of IBTs and also score the highest on both the rating systems, thus following the trend that as the number of IBTs used in the building increases so does its BREEAM/LEED score.

\subsection{Bivariate Correlation Analysis}

To inspect the correlation between the two variables, scatterplots (Figure $4 \& 5$ ) were requested using the SPSS analytics software. The scatterplots helped assess whether the two variables being investigated are closely related to one another and how closely the data conforms to a trend line. It was hypothesized that if IBTs enhanced the sustainability of a building then as the number of IBTs used in a building increased their BREEAM/LEED score would also increase. The percentage BREEAM and LEED scores are the dependant variables on the $\mathrm{x}$-axis while the number of IBTs are the independent variables on the $y$-axis (Figure $4 \& 5$ ).

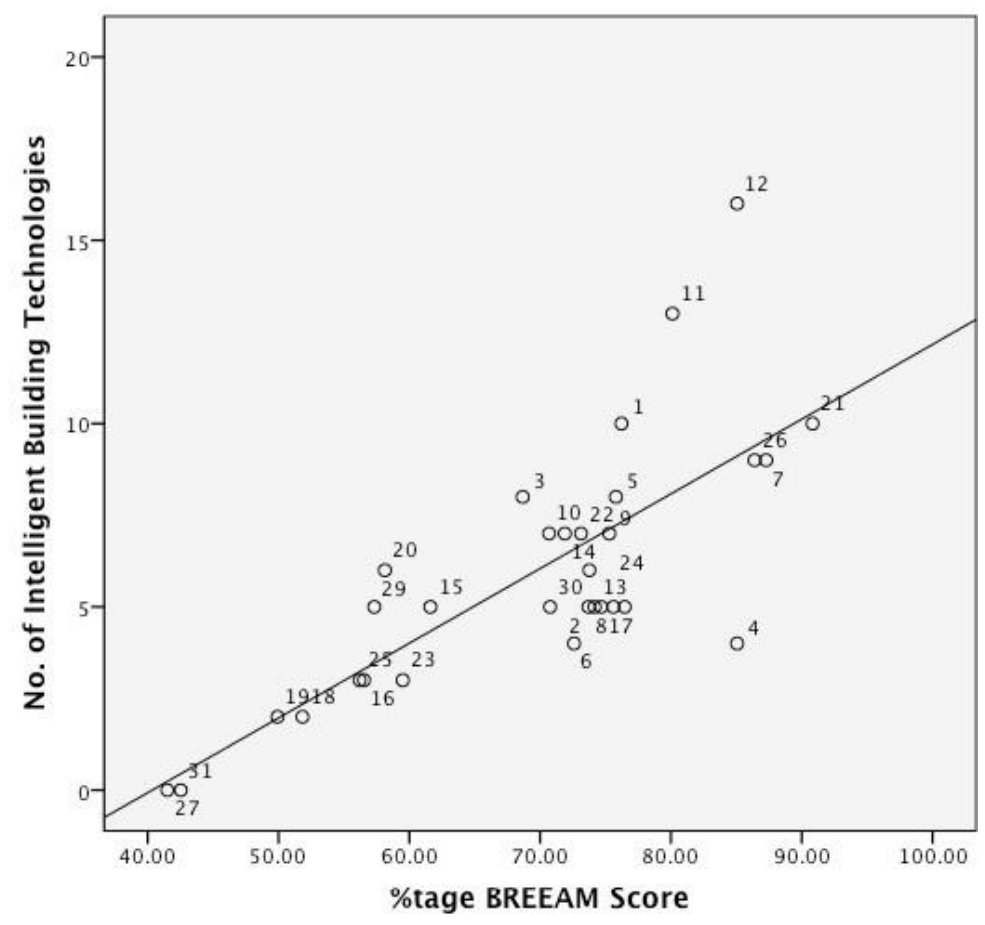

Figure 4: Bivariate correlation between the number of IBTs and Breeam scores 


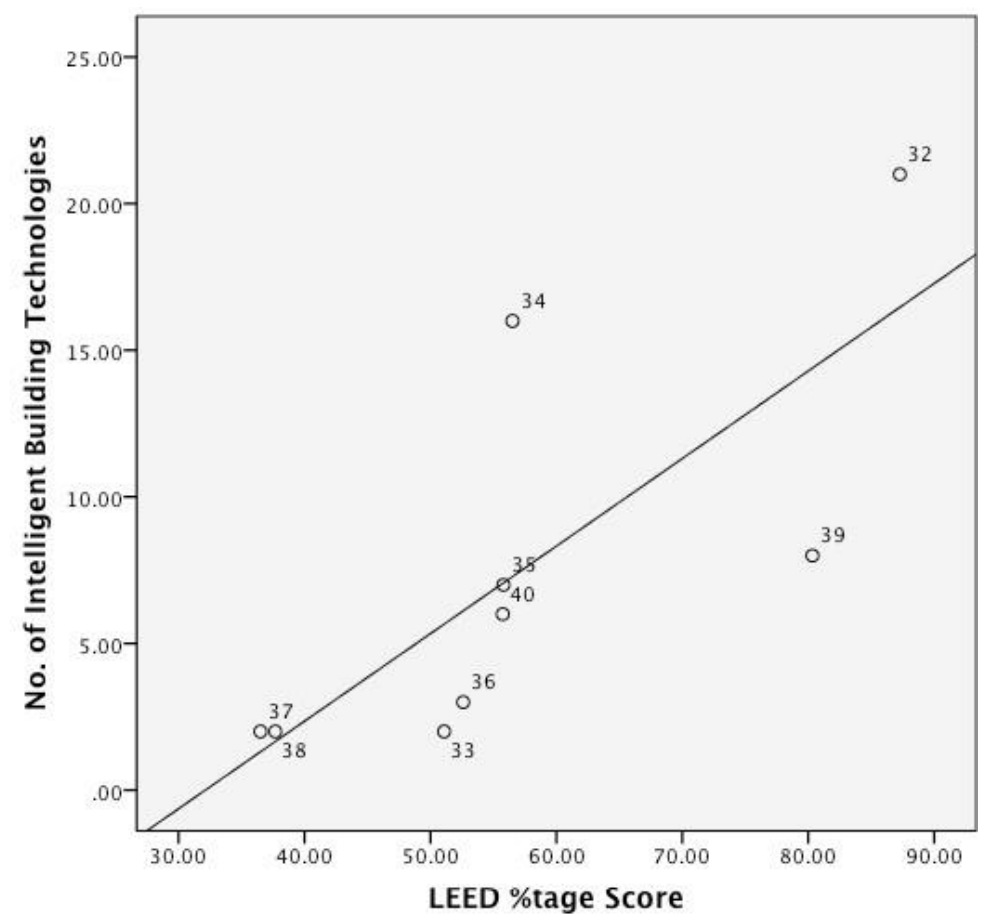

Figure 5: Bivariate correlation between the number of IBTs and Leed scores

The strength of the relationship between the number of IBTs used in a building and the percentage BREEAM/LEED score obtained by the building can be summarised by the coefficient R. According to Cohen (1988) magnitudes $0.10,0.30$ and 0.50 correspond roughly to relations that are considered small, medium and large respectively. An $\mathrm{R}$ value (Pearson Correlation) of 0.759 (Table 2) and 0.748 (Table 3) signals a very strong correlation between the variables, one that is highly significant. The fact that the sign of $R$ is positive indicates that as the number of IBTs used in a building increases, the value of the BREEAM and LEED score increases as well. The $R^{2}$ value is a standardised coefficient, which ranges from 0 to $1 ; 1$ indicates a perfect fit of the data points to a straight line and 0 indicates the worst possible fit. An $R^{2}$ value of 0.576 (Table 2) and 0.559 (Table 3) suggests a high number of data points that fit the trend line.

Table 2. Model Summary BREEAM Case Studies (linked to Figure 4)

\begin{tabular}{ccccc}
\hline Model & $\mathrm{R}$ Value & $\mathrm{R}^{2}$ Value & $\begin{array}{c}\text { Adjusted } \mathrm{R}^{2} \\
\text { Value }\end{array}$ & $\begin{array}{c}\text { Std. Error of } \\
\text { the Estimate }\end{array}$ \\
\hline 1 & $.759^{\mathrm{a}}$ & $\mathbf{. 5 7 6}$ & .562 & 8.51692 \\
\hline
\end{tabular}

Table 3. Model Summary LEED Case Studies (linked to Figure 5)

\begin{tabular}{ccccc}
\hline Model & $\mathrm{R}$ Value & $\mathrm{R}^{2}$ Value & $\begin{array}{c}\text { Adjusted } \mathrm{R}^{2} \\
\text { Value }\end{array}$ & $\begin{array}{c}\text { Std. Error of } \\
\text { the Estimate }\end{array}$ \\
\hline 1 & $\mathbf{. 7 4 8}$ & $\mathbf{. 5 5 9}$ & .497 & 12.06162
\end{tabular}

a. Predictors: (Constant), No. of Intelligent Building Technologies

b. Dependent Variable: Percentage BREEAM Score 
Additionally an ANOVA test of significance was carried out to show whether the $\mathrm{R}^{2}$ value for the relation between the two variables is significant. Since in this case the value of Significance is 0.000 (Table 4) and 0.020 (Table 5), which is less than 0.05 , the relation between the two variables is significantly different than zero, meaning the $R^{2}$ value is highly significant.

Table 4. ANOVA Test of Statistical Significance (BREEAM) (linked to Figure 4)

\begin{tabular}{ccccccc}
\hline & & Sum of & & & & \\
& Model & Squares & df & Mean Square & $F$ & Sig. \\
\hline 1 & Regression & 2861.747 & 1 & 2861.747 & $\mathbf{3 9 . 4 5 2}$ & $\mathbf{. 0 0 0}^{\mathbf{b}}$ \\
& Residual & 2103.600 & 29 & 72.538 & & \\
\hline & Total & 4965.347 & 30 & & & \\
\hline
\end{tabular}

Table 5. ANOVA Test of Statistical Significance (LEED) (linked to Figure 5)

\begin{tabular}{ccccccc}
\hline & Sum of & & & & \\
& Model & Squares & df & Mean Square & $\mathrm{F}$ & Sig. \\
\hline 1 & Regression & 1293.211 & 1 & 1293.211 & $\mathbf{8 . 8 8 9}$ & $\mathbf{. 0 2 0}^{\mathbf{b}}$ \\
& Residual & 1018.378 & 7 & 145.483 & & \\
& Total & 2311.589 & 8 & & & \\
\hline
\end{tabular}

a. Predictors: (Constant), No. of Intelligent Building Technologies

b. Dependent Variable: Percentage BREEAM Score

\subsection{Overview of the Correlation Analysis}

It was observed that the number of IBTs in a building positively affects its sustainability ratingas the number of IBTs used in a building increases their BREEAM/LEED score also increases. Some related findings about the impact different type of IBTs have are as follows:

- Highly integrated and interactive IBTs such as BMS, EMS and FMS were predominantly found in buildings with a high Sustainability Rating (EXCELLENT, OUTSTANDING, GOLD and PLATINUM).

- Buildings with BMS and integrated systems, which shared data and interacted with other building systems scored better than those with stand-alone systems.

- Buildings that made use of FMS, building commissioning and energy \& economic modelling scored better.

- Buildings with an intelligent HVAC control system scored better than those with intelligent lighting systems.

- IBTs that laid more emphasis on energy and cost efficiency scored better than those which emphasised comfort and convenience; network connectivity and AV control; and water saving features.

\section{Relationship Development}

\subsection{Regression Analysis and 5-Fold Cross Validation}

As a means of further exploring the complex relationship between the two variables, regression analysis, 5-fold cross validation and tests of significance ( $F$-test in ANOVA and t-test) were carried out. In this paper the data from the BREEAM certified case studies has been analysed 
to demonstrate the method used to develop a relationship between building intelligence and sustainability in the form of a predictive statistical model.

The BREEAM certified buildings were separately, randomly partitioned into 5 equal size subsamples but care was taken such that each set contained a mix of all the rating categories. At every fold: of the 5 subsamples, a single subsample was retained as the validation data for testing the model, and the remaining 4 subsamples were used as training data. The crossvalidation process was then repeated 5 times, with each of the 5 subsamples used exactly once as the validation data. The training sets helped obtain the best-fit model and the corresponding test set helped validate the accuracy of that model.

The models were developed using percentage BREEAM scores as the dependant variables and the number of IBTs as the independent variables. The regression models obtained at every fold (linear, logarithmic, quadratic and cubic) were tested on the corresponding test sets so as to obtain an insight on how the models would generalise to an unknown data set. This procedure estimated how accurately the predictive model would perform in practice i.e. accurately predict the Sustainability scores of buildings depending on the IBTs used. Also the standardised errors of each of the models were calculated by using the Predicted versus Actual BREEAM scores, and reported at every fold so as to identify the best-fit predictive model. $R$ and $R^{2}$ values of each model were reported and an Anova and T-test of significance were conducted. After reviewing the $R$ and $R^{2}$ values and the average standardised error of all the models across every test set, the logarithmic model was considered as the best fit predictive model. It was observed that though the $R$ and $R^{2}$ values were significantly high and positive in value in all cases (linear, logarithmic, quadratic and cubic), suggesting a strong positive correlation between the two variables, the logarithmic model performed very highly in comparison with the other models. 


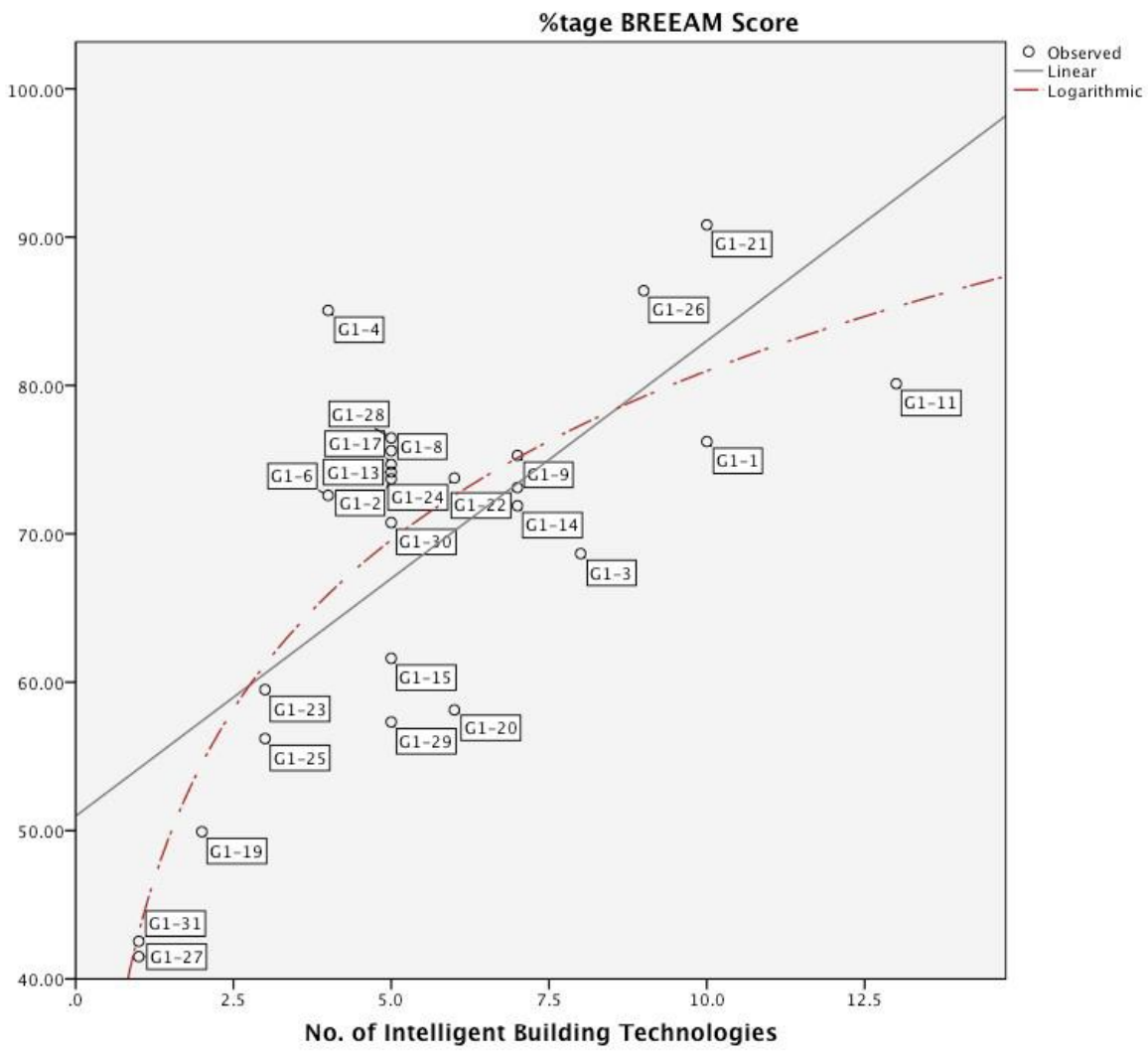

Figure 6: Logarithmic model for Breeam-certified buildings using test set 3 as an example

To describe the relationship development process in detail the predictive model obtained when Set 3 was used as the test set has been selected as an example (Figure 6). First, basic tests of statistical significance and correlation were conducted and then the behaviour of the logarithmic model was explained:

- All of the buildings that have used 0 to 5 numbers of IBTs in them and have scored either a GOOD or a VERY GOOD rating have caused the graph to rise exponentially in almost a linear manner at the start.

- The buildings in the curved portion of the graph have used 6 to 9 numbers of IBTs in them and scored an EXCELLENT rating. It can be observed that in these buildings the relative rise in the BREEAM score with the number of technologies used is not as drastic as observed in the earlier set of buildings causing the linear graph to slowly start to curve.

- Buildings G1-1, 3, 11, 12 and 21 follow a stabilising rise along the curvilinear path. All of these buildings have used 10 to 16 numbers of IBTs in them and only scored an EXCELLENT rating. It can be observed that though these buildings have a higher number of IBTs used in them their BREEAM scores have not drastically increased, as has occurred with the buildings with lower numbers of IBTs. This behaviour was attributed to the type of IBTs used and the core functions they perform. 
Table 6. Model Summary of BREEAM Test Set 3 (linked to Figure 6)

\begin{tabular}{c|c|r|r}
\hline $\mathrm{R}$ & \multicolumn{1}{|c|}{$\mathrm{R}^{2}$} & \multicolumn{1}{|c|}{ Adjusted $\mathrm{R}^{2}$} & Std. Error of the Estimate \\
\hline .812 & .659 & .644 & 7.583 \\
\hline
\end{tabular}

The independent variable is the No. of Intelligent Building Technologies.

Table 7. ANOVA Test of Statistical Significance (BREEAM Test Set 3) (linked to Figure 6)

\begin{tabular}{l|r|r|r|r|r}
\hline & Sum of Squares & \multicolumn{1}{|c|}{$\mathrm{df}$} & Mean Square & F & \multicolumn{1}{c}{ Sig. } \\
\hline Regression & 2558.187 & 1 & 2558.187 & $\mathbf{4 4 . 4 9 4}$ & $\mathbf{0 0 0}$ \\
Residual & 1322.385 & 23 & 57.495 & & \\
Total & 3880.573 & 24 & & & \\
\hline
\end{tabular}

The independent variable is the No. of Intelligent Building Technologies.

Table 8. Coefficients and t-test of Statistical Significance (BREEAM Test Set 3) (linked to Figure 6)

\begin{tabular}{|c|c|c|c|c|c|}
\hline & \multicolumn{2}{|c|}{ Unstandardized Coefficients } & \multirow{2}{*}{$\begin{array}{c}\begin{array}{c}\text { Standardized } \\
\text { Coefficients }\end{array} \\
\text { Beta }\end{array}$} & \multirow[b]{2}{*}{$\mathrm{t}$} & \multirow[b]{2}{*}{ Sig. } \\
\hline & $B$ & Std. Error & & & \\
\hline $\begin{array}{l}\text { Ln (No. of } \\
\text { Intelligent Building } \\
\text { Technologies) } \\
\text { (Constant) }\end{array}$ & $\begin{array}{l}16.444 \\
43.120\end{array}$ & $\begin{array}{l}2.465 \\
4.171\end{array}$ & .812 & $\begin{array}{r}6.670 \\
10.337\end{array}$ & $\begin{array}{l}.000 \\
.000\end{array}$ \\
\hline
\end{tabular}

An $R$ value of 0.812 (Table 6) signals a very strong relation between the variables, one that is highly significant. The fact that the sign of $R$ is positive indicates that as the number of IBTs increases, the value of the BREEAM score increases as well. An $\mathrm{R}^{2}$ value of 0.659 (Table 6) suggests a high variance of $65.9 \%$ and that a high number of data points fit the logarithmic model. The value of Significance (Sig.) is 0.000 (Table 7), which is less than 0.05 , it can be reported that the number and type of IBTs are highly significant in determining the BREEAM score. By default, the null hypothesis for a t-statistic is that the coefficient for the independent variable is zero, which is the same as saying that the independent variable does not help in predicting the dependant variable. After observing the t-statistic for the 'No. of intelligent building technologies' in Table 8, the value of its Significance (Sig.) can be noted as 0.000 . Since the $p$ value is less than 0.05 it can be assumed that the number of IBTs have a predictive ability for the BREEAM score. Table 8 also provides the parameters of the equation of the best-fitting logarithmic curve for predicting the estimate BREEAM score from the number of IBTs (Equation 1.). Equation 1. can be used to predict the estimate BREEAM Score of a building based on the number of IBTs used and vice versa.

Predicted BREEAM Score $=43.12+16.44 \times \log x$

1.

( $x=$ number of intelligent building technologies)

\subsection{Inference from the Regression Analysis}

Though the previous section (4.1) describes in detail the analysis and results of only BREEAM certified case studies, the overall trends highlighted in Figure 6 were commonly observed in the 
study of both BREEAM and LEED certified buildings. To discuss in detail the kind of influence the types of IBTs had on the sustainability scores, two sets were formed (Table 9): one containing all the common intelligent building technologies found in buildings with 0 to 5 number of IBTs and the second with 10 and over number of IBTs.

Table 9. Common Set of Intelligent Building Technologies found in all Case Studies

\begin{tabular}{|c|c|}
\hline Set 1 & $\begin{array}{c}\text { Set } 2 \text { (Set } 2 \text { comprises of Set } 1+\text { the IBTs } \\
\text { below) }\end{array}$ \\
\hline Lighting Management System & $\begin{array}{l}\text { Intelligent Security system- integration of } \\
\text { CCTV, entry control devices, alarms and } \\
\text { emergency security lighting }\end{array}$ \\
\hline $\begin{array}{l}\text { Occupancy, Daylight sensors and } \\
\text { Programmed timers for lighting }\end{array}$ & $\begin{array}{l}\text { Surveillance system with real time security } \\
\text { feeds }\end{array}$ \\
\hline $\begin{array}{l}\text { Operable windows and sun-shades with night- } \\
\text { time air flush }\end{array}$ & $\begin{array}{l}\text { Computerised Smartcard access control } \\
\text { system with proximity and contact cards }\end{array}$ \\
\hline $\begin{array}{l}\text { Intelligent HVAC system with zoning and heat } \\
\text { recovery }\end{array}$ & Intelligent Visitor Access System \\
\hline $\begin{array}{l}\text { Demand controlled ventilation system with } \\
\mathrm{CO}_{2} \text { monitoring }\end{array}$ & $\begin{array}{l}\text { Fire Protection System incorporating fire } \\
\text { detection and Automatic sprinkler system }\end{array}$ \\
\hline Space temperature sensors & $\begin{array}{l}\text { Fire Protection system integrated with HVAC } \\
\text { system to automatically cut off zones where } \\
\text { smoke is detected }\end{array}$ \\
\hline Occupancy sensors for plug loads & $\begin{array}{l}\text { Addressable fire safety detectors to } \\
\text { continuously take air samples and detect } \\
\text { unusual fog }\end{array}$ \\
\hline Sub- & CCTVs all over the building for fire monitoring \\
\hline PIR t & $\begin{array}{l}\text { Smoke exhaust system that activates during a } \\
\text { fire }\end{array}$ \\
\hline Water leak detection system & $\begin{array}{l}\text { IAQ management plan with temperature \& } \\
\text { humidity sensors and UV emitters }\end{array}$ \\
\hline Water usage monitoring & Refrigerant leak detection system \\
\hline e monitoring & Automated Destination-controlled lift system \\
\hline s monitoring & Elevators with Smart Card access system \\
\hline $\begin{array}{l}\text { IT networks for data transfer, integration and } \\
\text { telecommunication (ICS) }\end{array}$ & $\begin{array}{l}\text { Guard Tour System to track security } \\
\text { inspections }\end{array}$ \\
\hline $\begin{array}{l}\text { Simulation tools for energy, light and } \\
\text { economic modelling }\end{array}$ & Multiple communications risers \\
\hline Building Management System (BMS) & Intelligent AV control systems \\
\hline Energy Management System (EMS) & Intelligent Document management system \\
\hline \multirow[t]{3}{*}{ Facilities Management System (FMS) } & Soil moisture sensors \\
\hline & Solar tracking devices \\
\hline & $\begin{array}{l}\text { Simulation tools for airflow and temperature } \\
\text { modelling }\end{array}$ \\
\hline
\end{tabular}

It can be observed in Table 9 that almost all of the IBTs in Set1 contribute towards resource efficiency. These IBTs help with energy and water savings as well as $\mathrm{CO}_{2}$ reductions, hence leading to a linear rise in the graph. This led them to follow a linear path such that as intelligence increased, sustainability also increased. On the other hand, the buildings with a high number of IBTs usually had a larger variety of technologies in terms of their core intelligence function- resource efficiency, interaction, safety, comfort, etc. The IBTs in Set2 also contributed towards resource efficiency but at the same time there were a number of other IBTs used that primarily aided with other things such as convenience, comfort, security, increased connectivity, 
etc. This caused their sustainability scores to increase but not in a drastic one-to-one linear fashion but in a gradually rising curve. It can be inferred that the score increased due to the resource efficient IBTs present, but the score was adversely affected by some of the other IBTs. Though many of the technologies in Set2 are of higher intelligence, and continue to improve the overall intelligence of the building, they may not necessarily contribute towards the sustainability of the building in terms of the prescriptive parameters set by LEED and BREEAM.

For example, lighting systems with occupancy and daylight sensors were created to improve energy efficiency. They were specifically designed to make energy saving smarter, while there are other systems:

- Intelligent Security and access control system whose role is to make buildings safe.

- Intelligent Fire Safety system whose intelligence lies in implementing smart ways to detect and extinguish fires.

- Indoor Air Quality management system whose task is to self-monitor temperature, humidity and freshness of air for comfort and protection from diseases.

- Integrated Communications Systems, AV systems and document management systems, which improve productivity in the workplace.

\section{Discussion}

The findings from the regression analysis has proved that achieving sustainability is one of the many features of building intelligence and by using the predictive model (Equation 2.) developed by this research one can predict the estimate Sustainability Score of a building based on the number of IBTs used, though the type of IBTs used could affect the score. To elaborate, the type of IBTs used cannot be quantitatively analysed by the proposed predictive model and therefore they can be an altering factor. But it can be agreed that building intelligence is one of the many features of sustainability.

Predicted BREEAM/LEED Score $=a+b \times \log x$

2.

$$
\text { ( } x=\text { number of intelligent building technologies; } \mathrm{a} \& \mathrm{~b} \text { are constants) }
$$

BREEAM and LEED rating systems calculate the sustainability value of a building based on various set parameters. Though LEED and BREEAM are both well-established rating systems, there has been a growing chorus of critics which have taken issue with the point-based systems. The most commonly cited example in LEED 2009 v3 being, developers get the same number of points for installing a bike rack as they do for a complex water recycling system (Leonard, 2010; USGBC, 2016). One can argue that the introduction of LEED and BREEAM have stimulated research into the building sciences though there is a lot to be done to perfect them. The findings from this research also substantiate that sole reliability on prescriptive parameters is not a good idea. While developing a Rating System for evaluating a building's 
cumulative intelligence and sustainability, a more holistic approach should be considered. (BSRIA, 2009; Starrs, 2010; Haroglu, 2013)

Building intelligence is multi-dimensional, just like BREEAM and LEED, and can be categorised according to parameters such as resource efficient, dynamically responsive, self-monitoring, interactive within themselves and with people, comfort, safety, security, etc. Thus it was inferred from this study that intelligent buildings could also be defined in terms of the core intelligence functions of their systems based on what aspect of the building they made smarter. From the regression analysis one can clearly observe that ensuring a building is resource efficient is just one part of its being intelligent. If resource efficiency were the only definitive trait of intelligent buildings then a linear model would best describe the relation between the variables in question. The example of multiple LCD screens as part of an intelligent Security System help make the point. These screens require additional energy but if the function of the building were to protect highly classified data, then having a building, which ensures high standards of security would be of much more relevance than energy efficiency. This highlights that building functionality is a defining factor and by consequence of inter-relatability, so are the occupants' needs. The users of this hypothetical building require a highly secure facility with state-of-art intelligent security equipment for the business to flourish and increase their productivity and job satisfaction.

Hence it can be inferred that to have an 'Intelligently-Sustainable' building, the level of building intelligence and sustainability has to be optimised taking into consideration the function of the building and the occupants' immediate needs thus achieving both environmental and social sustainability. This research has proved that one can achieve an intelligent and sustainable building but there is an optimisation level where one of the two will gain priority. This priority or the weighting value can be ultimately decided by the users' needs and the building's functionality. Current literature (Wacks, 2002; Clements-Croome, 2004; Liu et al., 2010; Gadakari et al., 2014) suggests that the users' behaviour and interaction with the intelligent environment plays an important role in the performance of technologies. In order to maximise user acceptability and encourage the shift to socio-technical interactions certain issues need to be considered: assessment of user needs (Cole and Brown, 2009; Chen et al., 2010; Karjalainen, 2010); determining the amount of personal control (Baird and Lechat, 2009); safety and security (Farinloye et al., 2013); effect on occupant behaviour, efficiency and productivity (Matthew et. al, 2009; Gadakari et al., 2012); comfort and wellbeing (Chappells, 2010; Wu and Noy, 2010); and privacy-related issues (Moran and Nakata, 2010).

In a building rating system every parameter has a weighted value which decides its relative importance among its peer parameters (BRE, 2016; USGBC, 2016). Along with individual weighted values the 'Intelligently-Sustainable' building rating system can have an overall weighting system that determines which branch deserves priority so as to have an optimised level of intelligence and sustainability. Thus the predictive model developed through this 
research will need to be further worked upon such that it not only includes the number and type of IBTs but also considers the users' needs and the buildings function. The new rating system with its consideration to users and building functions will thus overcome the limitations of traditional building rating systems with prescriptive parameters.

\section{Conclusion}

This paper highlights the various benefits IBTs can provide and the bivariate correlation analysis proves that there is a strong positive correlation between the number of IBTs used in a building and the BREEAM and LEED score achieved. The regression analysis and the 5-fold cross validation process has proved through multiple iterations that the logarithmic model is the bestfit model that describes the true relationship between the multi-dimensional entities i.e. building intelligence and sustainability. It also helped infer the effect, different kinds of IBTs have on the sustainability value of a building. The findings led to a discussion about the importance of optimisation between building intelligence and sustainability based on user needs and the building's core function. A Predictive Statistical model was also generated that can be used to predict the estimate Sustainability Score of a building based on the number of IBTs used and vice versa.

With the aid of this Predictive Model, this paper wants to introduce intelligence as a new kind of sustainability parameter, and would argue that it needs to be added as an extension for additional points to Green Building Rating Systems so that one can evaluate the sustainability value of a building based on the number and type of IBTs used and vice versa. This could facilitate the redesign of BREEAM and LEED systems. It could also pave the way for a new independent building rating system that will cumulatively evaluate building intelligence and sustainability. To conclude, this paper highlights the concept of Sustainable-Intelligence such that new construction is held to a high standard of being intelligent and sustainable.

\begin{tabular}{|c|c|c|c|c|}
\hline \multicolumn{5}{|l|}{ Appendix } \\
\hline $\begin{array}{l}\text { Building } \\
\text { ID }\end{array}$ & Name of Building & Location & $\begin{array}{c}\text { Building } \\
\text { Rating } \\
\text { System }\end{array}$ & $\begin{array}{l}\text { Rating Type } \\
\text { Achieved }\end{array}$ \\
\hline G1-1 & 16 Noel Street & London, UK & BREEAM & EXCELLENT \\
\hline G1-2 & $\begin{array}{c}\text { Ceredigion County Council } \\
\text { Offices }\end{array}$ & Aberystwyth, UK & BREEAM & EXCELLENT \\
\hline G1-3 & $\begin{array}{c}\text { Church View House, DWP } \\
\text { Offices }\end{array}$ & Seaham, UK & BREAAM & EXCELLENT \\
\hline G1-4 & Horizon House & Bristol, UK & BREEAM & EXCELLENT \\
\hline G1-5 & Welsh Assembly Building & Llandudno, UK & BREEAM & EXCELLENT \\
\hline G1-6 & Cabot Circus & Bristol, UK & BREEAM & EXCELLENT \\
\hline G1-7 & Lion House & Alnwick, UK & BREEAM & OUTSTANDING \\
\hline G1-8 & Met Office & Exeter, UK & BREEAM & VERY GOOD \\
\hline G1-9 & Waterways Ireland & Enniskillen, UK & BREEAM & EXCELLENT \\
\hline G1-10 & $\begin{array}{l}\text { Welsh Assembly } \\
\text { Government Offices }\end{array}$ & Aberystwyth, UK & BREEAM & EXCELLENT \\
\hline G1-11 & Dashwood House & London, UK & BREEAM & EXCELLENT \\
\hline
\end{tabular}




\begin{tabular}{|c|c|c|c|c|}
\hline G1-12 & $\begin{array}{c}\text { Herman Miller International } \\
\text { Headquarters }\end{array}$ & Chippenham, UK & BREEAM & EXCELLENT \\
\hline G1-13 & White River Place & St Austell, UK & BREEAM & EXCELLENT \\
\hline G1-14 & Kelway Office Building & Peterborough, UK & BREEAM & EXCELLENT \\
\hline G1-15 & Asda & Sheffield, UK & BREEAM & VERY GOOD \\
\hline G1-16 & Lidl & York, UK & BREEAM & VERY GOOD \\
\hline G1-17 & $\begin{array}{c}\text { Marks \& Spencer Cheshire } \\
\text { Oaks }\end{array}$ & Liverpool, UK & BREEAM & EXCELLENT \\
\hline G1-18 & 8-12 Sur Parc & Paris, France & BREEAM & GOOD \\
\hline G1-19 & Carré Vert & Paris, France & BREEAM & GOOD \\
\hline G1-20 & Le Mermoz & $\begin{array}{l}\text { Le Bourget, } \\
\text { France }\end{array}$ & BREEAM & VERY GOOD \\
\hline G1-21 & Spring 53 Rue du Port & Nanterre, France & BREEAM & OUTSTANDING \\
\hline G1-22 & SO Quest & Paris, France & BREEAM & EXCELLENT \\
\hline G1-23 & $\begin{array}{c}\text { Atlantis Bridge and Access } \\
\text { Buildings }\end{array}$ & Brussels, Belgium & BREEAM & VERY GOOD \\
\hline G1-24 & Oude Houtlei 140 & Ghent, Belgium & BREEAM & EXCELLENT \\
\hline G1-25 & Trinity Park III & Warsaw, Poland & BREEAM & VERY GOOD \\
\hline G1-26 & $\begin{array}{l}\text { Goeppert-Mayer office } \\
\text { building }\end{array}$ & Katowice, Poland & BREEAM & OUTSTANDING \\
\hline G1-27 & Centro Commercial Coruña & Galicia, Spain & BREEAM & GOOD \\
\hline G1-28 & Centrum Galerie & $\begin{array}{l}\text { Dresden, } \\
\text { Germany }\end{array}$ & BREEAM & EXCELLENT \\
\hline G1-29 & Greenstore Stamata & Athens, Greece & BREEAM & VERY GOOD \\
\hline G1-30 & $\begin{array}{l}\text { European Investment Bank } \\
\text { Office Building }\end{array}$ & $\begin{array}{l}\text { Luxembourg, } \\
\text { Luxembourg }\end{array}$ & BREEAM & EXCELLENT \\
\hline G1-31 & Olimpia Business Center & $\begin{array}{l}\text { Cluj-Napoca, } \\
\text { Romania }\end{array}$ & BREEAM & GOOD \\
\hline G1-32 & Hollywood House & Woking, UK & LEED & PLATINUM \\
\hline G1-33 & Symantec Green Park & Reading, UK & LEED & SILVER \\
\hline G1-34 & $\begin{array}{c}\text { Herman Miller International } \\
\text { Headquarters }\end{array}$ & Chippenham, UK & LEED & GOLD \\
\hline G1-35 & HOK London Office & London, UK & LEED & GOLD \\
\hline G1-36 & Medtronic Ltd & Watford, UK & LEED & SILVER \\
\hline G1-37 & $\begin{array}{c}\text { Levi Strauss Store Passage } \\
\text { Du Havre }\end{array}$ & Paris, France & LEED & CERTIFIED \\
\hline G1-38 & American Embassy & Sofia, Bulgaria & LEED & CERTIFIED \\
\hline G1-39 & Green Tower Office Centre & $\begin{array}{l}\text { Gothenburg, } \\
\text { Sweden }\end{array}$ & LEED & PLATINUM \\
\hline G1-40 & $\begin{array}{l}\text { Riga Stokholm Office } \\
\text { Pennfõktaren } 11\end{array}$ & $\begin{array}{l}\text { Stockholm, } \\
\text { Sweden }\end{array}$ & LEED & GOLD \\
\hline
\end{tabular}

\section{References}

Baird G and Lechat S (2009) Users' Perceptions of Personal Control of Environmental

Conditions in Sustainable Buildings. Architectural Science Review 52(2): 108-116.

BRE (Building Research Establishment) (2016) What is BREAAM? See

http://www.breeam.com/index.jsp (accessed 01/03/2016).

BSRIA (Building Services Research and Information Association) (2009) BREEAM or LEED strengths and weaknesses of the two main environmental assessment methods. See https://www.bsria.co.uk/news/article/breeam-or-leed-strengths-and-weaknesses-of-the-twomain-environmental-assessment-methods/ (accessed 19/06/2013).

Chappells H (2010) Comfort, well-being and the socio-technical dynamics of everyday life. Intelligent Buildings International 2(4): 286-298. 
Chen J, Ma Y, Jeng T and Chang C (2010) An assessment of user needs for intelligent living space. Intelligent Buildings International 2(1): 20-40.

Cheshire D (2012) LEED vs BREEAM: What's best? See http://www.edie.net/library/LEED-vsBREEAM-Whats-best/6124 (accessed 01/03/2016)

Clarke E (2008) The truth about... intelligent buildings. See http://www.climatechangecorp.com/content.asp?ContentID=5471/ (accessed 15/02/2012).

Clements-Croome TDJ (1997) What do we mean by intelligent buildings? Automation in Construction 6(5-6): 395-400.

Clements-Croome TDJ (ed.) (2004) Intelligent Buildings: Design, Management and Operation. Thomas Telford, London, UK.

Cohen J (1988) Statistical power analysis for the behavioral sciences (2nd ed). Lawrence Erlbaum, New Jersey, USA.

Cole R and Brown Z (2009) Reconciling human and automated intelligence in the provision of occupant comfort. Intelligent Buildings International 1(1): 39-55.

Creswell J (2009) Research Design: Qualitative, Quantitative and Mixed Methods Approaches (3rd ed). SAGE Publications Ltd., London, UK.

Ehrlich P (2007) Intelligent Buildings Today. See http://www.greenintelligentbuildings.com/Articles/Cover Story/BNP GUID 9-52006 A 10000000000000056794/ (accessed 09/05/2010).

Farinloye O, Odusami K and Adewunmi Y (2013) Theft and Vandalism Control Measures on Building Sites in Lagos, Nigeria. Journal of Engineering, Project, and Production Management 3(1): 9-21.

Gadakari T, Fotios S, Mushatat S and Newman R (2012) Exploring the Social Aspect of Sustainability in Intelligent Environments. In Proceedings of the 4th CIB Conference on Smart and Sustainable Built Environments - SASBE2012: Emerging Economies (Gomes V (ed)). Fundação de Desenvolvimento da UNICAMP - Funcamp, São Paulo, Brazil, pp. 273284.

Gadakari T, Mushatat S and Newman R (2014) Intelligent Buildings: Key to Achieving Total Sustainability in the Built Environment. Journal of Engineering, Project, and Production Management 4(1): 2-16.

Garner R (1996) Environmental Politics. Harvester Wheatsheaf, Hertfordshire, UK.

Harris F (2004) Human-Environment Interactions. In Global Environmental Issues (Harris F (ed.)). John Wiley \& Sons Ltd., West Sussex, UK.

Harrison A, Loe E and Read J (1998) Intelligent Buildings in South East Asia. Taylor \& Francis Routledge, London, UK.

Haroglu $H$ (2013) The impact of Breeam on the design of buildings. Proceedings of the Institution of Civil Engineers - Engineering Sustainability 166(1): 11-19.

Hollywood House (2013) Hollywood House Woking. See http://www.hollywoodhousewoking.co.uk/green/index.html/ (accessed 05/01/2013). 
Karjalainen S (2010) Usability guidelines for room temperature controls. Intelligent Buildings International 2(1): 85-97.

Kinver M (2011) People power 'overlooked by energy policies'. See http://www.bbc.co.uk/news/science-environment-12417359 (accessed 12/05/2013).

Kurzweil R (2005) The Singularity is Near: When Humans Transcend Biology. Penguin Group, New York, USA.

Leonard A (2010) Architect Frank Gehry talks LEED and the future of green building. See http://www.pbs.org/wnet/need-to-know/culture/architect-frank-gehry-talks-leed-and-thefuture-of-green-building/1458/ (accessed 09/07/2015).

Liu K, Nakata K and Harty C (2010) Pervasive informatics: theory, practice and future directions. Intelligent Buildings International 2(1): 5-19.

Matthew P, Mukherjee M and Gupta V (2009) The Performance of Intelligent Buildings in India. The Institution of Engineers (India) Journal 90(April).

Moran S and Nakata K (2010) Analysing the factors affecting users in intelligent pervasive spaces. Intelligent Buildings International 2(1): 57-71.

Nikolaou T, Kolokotsa D and Stavrakakis G (2004) Introduction to Intelligent Buildings. In $A$ Handbook for Intelligent Buildings. SMART Accelerate, Athens, Greece.

Pitts A (2004) Planning and Design Strategies for Sustainability and Profit: Pragmatic sustainable design on building and urban scales. Architectural Press, Oxford, UK.

Robinson JF, Foxon TJ and Taylor PG (2016) Performance gap analysis case study of a nondomestic building. Proceedings of the Institution of Civil Engineers - Engineering Sustainability 169(1): 31-38.

Roderick Y, Mcewan D, Wheatley C and Alonso C (2012) A comparative study of building energy performance assessment between LEED, BREEAM and Green Star schemes. IESVE, Glasgow, UK.

Sharples S, Callaghan V and Clarke G (1999) A Multi-Agent Architecture for Intelligent building sensing and control. Sensor Review 19(2): 135-140.

Skanska (2012) Hollywood House, UK. See http://skanska-sustainability-casestudies.com/Case-Studies/Hollywood-House-UK/Page-1.html/ (accessed 10/01/2013).

Starrs M (2010) BREEAM versus LEED. Inbuilt Ltd. Kings Langley, Hertfordshire, UK.

USGBC (U.S. Green Building Council) (2016) About LEED. See http://www.usgbc.org/articles/about-leed (accessed 01/04/2016).

Wacks KP (2002) Best-Practices Guide for Evaluating Intelligent Building Technologies. CABA North America's Home \& Building Automation Association, Ottawa, Canada.

Wu S and Noy P (2010) A conceptual design of a wireless sensor actuator system for optimizing energy and well-being in buildings. Intelligent Buildings International 2(1): 41-56.

Yin RK (2009) Case Study Research: Design and Methods (4th ed). SAGE Publications Inc., California, USA. 